HYPOTHESIS

\title{
Reappraisal of the historical selective pressures for the CCR5-432 mutation
}

\author{
S R Duncan, S Scott, C J Duncan
}

J Med Genet 2005;42:205-208. doi: 10.1136/jmg.2004.025346

HIV strains are unable to enter macrophages that carry the CCR5- $\triangle 32$ deletion; the average frequency of this allele is $10 \%$ in European populations. A mathematical model based on the changing demography of Europe from 1000 to $1800 \mathrm{AD}$ demonstrates how plague epidemics, 1347 to 1670 , could have provided the selection pressure that raised the frequency of the mutation to the level seen today. It is suggested that the original single mutation appeared over 2500 years ago and that persistent epidemics of a haemorrhagic fever that struck at the early classical civilisations served to force up the frequency to about $5 \times 10^{-5}$ at the time of the Black Death in 1347 .

See end of article for authors' affiliations

Correspondence to: Professor C J Duncan School of Biological Sciences, University of Liverpool, Crown Street, Liverpool' L69 7ZB; sscoH@ liverpool.ac.uk

Revised version received 10 August 2004 Accepted for publication 11 August 2004
$\mathrm{T}$ he transmembrane CCR5 chemokine receptor is used by HIV strains to enter cells of the immune system such as macrophages and $\mathrm{CD}^{+}{ }^{+} \mathrm{T}$ cells. ${ }^{1-4}$ The CCR5-432 deletion prevents the expression of the receptor on the cell surface and provides almost complete resistance to HIV-l infection in homozygous individuals and partial resistance in the heterozygous state..$^{5-8}$ Later studies showed that men who were heterozygous had a $70 \%$ reduced risk of HIV infection compared with individuals who did not carry the mutation. ${ }^{9}$ The average frequency of the CCR5-432 deletion allele is estimated to be $10 \%$ in European populations, but it is virtually absent among native subSaharan African, Asian, and American Indian populations. ${ }^{5} 81011$ A north to south gradient in Europe was found, with the highest allele frequencies in Finnish and Russian populations (16\%) and the lowest in Sardinia (4\%). ${ }^{11}$ HIV has not existed long enough in the human population to account for this selection pressure. From computer analyses based on coalescent theory, the age of the CCR 5-432 bearing haplotype is thought to be approximately 700 years (but with a wide range of 275 to 1875 years). ${ }^{10}$ Here we present a population-genetic model, based on the demography of Europe, in which annual widespread epidemics of plague, a viral haemorrhagic fever, from 1347 until 1670 forced up the frequency of the $\Delta 32$ mutation to the present day values.

\section{PREVIOUS HYPOTHESES}

There have been various suggestions for the selection pressure that acted on the $\Delta 32$ mutation:
- The single pandemic of the Black Death (1347-50), assumed to be bubonic plague, ${ }^{10}$ which killed some $40 \%$ of the population of Europe. At most, this would merely have doubled the frequency from about $5 \times 10^{-5}$ to $10^{-4}$ (that is, if half the population are killed, the proportion of the protected, resistant individuals in the population would rise twofold).

- Epidemics of bubonic plague every 10 years for 400 years. Mathematical modelling shows that this hypothesis is not valid ${ }^{12}$ and, furthermore, it has been shown that Yersinia pestis, the bacterial pathogen of bubonic plague, does not use the CCR5 receptor for entry. ${ }^{13}$

- Smallpox epidemics every five years in Europe for at least 620 years from 1347 to $1970 .{ }^{12}$ This hypothesis also is not valid: a lethal form of smallpox appeared in England only in about $1628^{14}$ and before that date, smallpox was "not reputed to be a serious malady." ${ }^{15}$ Total annual smallpox deaths in London did not rise consistently above 1000 before $1710 .^{16}$ Variolation began in 1750 and vaccination in 1800 , and the number of deaths from smallpox declined dramatically thereafter and had disappeared from Europe by 1900. ${ }^{16}$ The disease would have had no effect whatsoever in forcing up the $\Delta 32$ frequency between 1900 and 1970. Thus smallpox could have acted effectively only during the period 1700 to 1830, whereas the modelling ${ }^{12}$ shows that over 600 years of epidemics would be required to raise the frequency to $10 \%$.

\section{HYPOTHESIS FOR THE SELECTION PRESSURE}

The area where the $\Delta 32$ mutation is found today corresponds exactly with the range of the plagues. It has been suggested ${ }^{17} 18$ that the pathogen responsible for the Black Death and all the subsequent plagues was an unknown emergent virus with a $100 \%$ case mortality which caused a haemorrhagic fever. To avoid confusion, we have named this disease haemorrhagic plague. ${ }^{17}$ We suggest that this virus also gained entry into the cells of the immune system through the CCR5 chemokine receptor and that the regular plague epidemics of the Middle Ages in Europe served to force up the frequency of the CCR5- 432 mutation in that area. Any populationgenetic model that seeks to explain the rise in the frequency of the CCR5-432 mutation must take into account the changes in the population structure of Europe, the mortality and immediate 


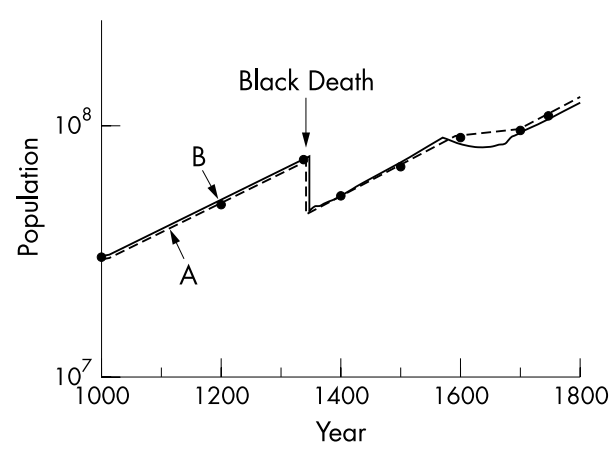

Figure 1 Line A (dashed line, solid circles): estimates of the population of Europe (ordinate, log scale) from 1000 to $1800 .{ }^{19}$ The single epidemic of the Black Death caused $40 \%$ mortality. Line B: growth of the population of Europe predicted by the model.

effect of the Black Death, and the changing spread of the plagues.

\section{MATRIX MODELLING}

The total population of Europe is estimated to have risen from $3 \times 10^{7}$ in $\mathrm{AD} 1000$ to $7.4 \times 10^{7}$ at the Black Death. ${ }^{19}$ Afterwards, it rose again from $5.3 \times 10^{7}$ in 1400 to $8.8 \times 10^{7}$ in 1600 (fig 1, line A); extrapolation of the line shows that the overall mortality in the Black Death was around $40 \%$. The rate of population growth in Europe was the same before and after the Black Death (fig 1, line A), but from 1600 to 1700 it was around zero. The number of places in Europe reporting plague epidemics each year is shown in fig $2^{20}$; the epidemics were more widespread after 1570 and suppressed population growth (fig 1, line A) and increased the selection pressure sharply.

In the model, the population is divided into three classes: susceptible homozygotes $(z)$, heterozygotes $(h)$, and resistant homozygotes $(r)$. Three state vectors, each with 65 entries, are defined, describing the number of women in each age group (that is, $0-1,1-2, \ldots 64-65$ ) within the three classes, at time $t$. We have previously reported the use of a conventional Leslie matrix to model such a population. ${ }^{16}{ }^{21}$

Mortality and fecundity affect the way in which the number of women in each age group evolves from $t$ to $t+1$. The annual probability of survival at age $x$ from all sources of mortality other than haemorrhagic plague $=\mu_{x}$. The function $\mu_{x}$ for female survival in the years without plague ( 1000 to $1346 ; 1670$ to 1800 ) is the stable age distribution Model West level 10, and during the plagues (1347 to 1670) it is Model West level 2. ${ }^{21}{ }^{22}$ The number of female offspring born

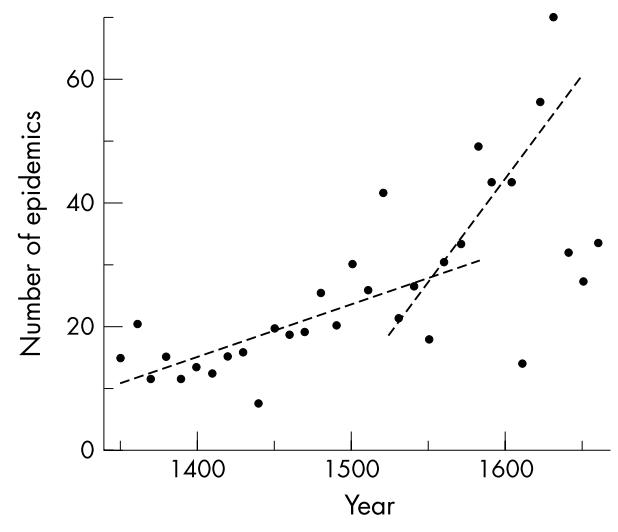

Figure 2 Number of places in Europe reporting a plague epidemic in each decade, 1350 to $1660 .{ }^{20}$ to a female of age $x=m_{x}$. The mean number of daughters born to a woman $=2.25 .{ }^{16}$ The incidence of the plague mortality (denoted by $\sigma$ in the model) consistent with fig 2 is $2.1 \%$ of the population per year from 1351 to 1574 and $2.65 \%$ per year from 1575 to 1670 .

The diploid model ${ }^{12}$ is based on a single locus with two alleles: a common allele at frequency $q$ in susceptible individuals and a rare dominant resistance allele at frequency $p=1-q$. The rare resistant homozygotes are assumed not to have died from the plague (that is, $i_{r}=0$ ). The heterozygotes may have caught the disease but did not die from it, for which there is substantial evidence, particularly in the 17th century $^{17}$ - that is, $i_{h}=0$. Susceptible homozygotes died from the disease $\left(i_{z}=1\right)$.

The population dynamics of the system are defined by difference equations, where changes in the number of susceptible homozygotes, heterozygotes, and resistant homozygotes in age class 1 during a single time step are given by ${ }^{12}$ :

$$
\begin{aligned}
& z_{1}(t+1)=\left(1-i_{z} \sigma\right) \mu_{1} \sum_{x=1}^{65} q_{x}(t)^{2} m_{x} n_{x}(t) \\
& h_{1}(t+1)=\left(1-i_{h} \sigma\right) \mu_{1} \sum_{x=1}^{65} 2 p_{x}(t) q_{x}(t) m_{x} n_{x}(t) \\
& r_{1}(t+1)=\left(1-i_{r} \sigma\right) \mu_{1} \sum_{x=1}^{65} p_{x}(t)^{2} m_{x} n_{x}(t)
\end{aligned}
$$

where $n_{x}(t)=z_{x}(t)+h_{x}(t)+r_{x}(t)$.

The dynamics of $z, h$, and $r$ in age classes 2 to 65 are given by:

$$
\begin{aligned}
& z_{x+1}(t+1)=\left(1-i_{z} \sigma\right) \mu_{x} z_{x}(t) \\
& h_{x+1}(t+1)=\left(1-i_{h} \sigma\right) \mu_{x} h_{x}(t) \\
& r_{x+1}(t+1)=\left(1-i_{r} \sigma\right) \mu_{x} r_{x}(t)
\end{aligned}
$$

The initial frequency of the resistant allele before the Black Death in 1347 is given by $p_{0}=5 \times 10^{-5} .^{12}$

\section{RESULTS OF THE MODELLING}

The growth of the population of Europe from 1000 to 1800 predicted by the model is shown in fig 1 , line B, and corresponds closely with the actual estimates. ${ }^{19}$ The predicted rise in frequency of the resistance allele from 1347 to 1670 , during which time it was forced up by the selection pressure of the plagues, is shown in fig 3. The final predicted gene frequency is $10 \%$.

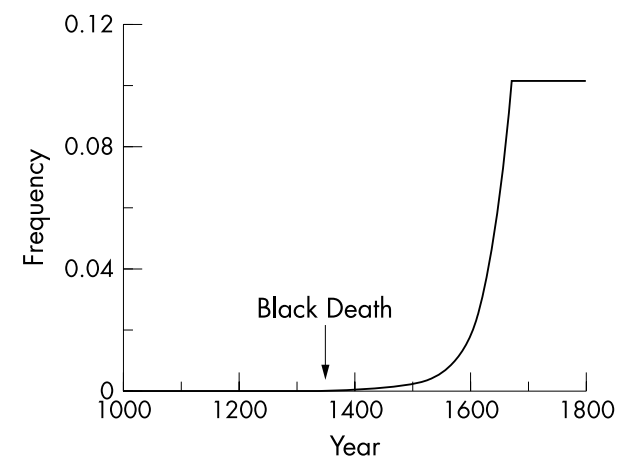

Figure 3 Rise in the frequency of the CCR5- $\triangle 32$ mutation between the Black Death and 1670, as predicted by the modelling. 


\section{DISCUSSION}

The results of the modelling are consistent with the data contained in figs $1 \mathrm{~A}$ and 2 and with the suggestion that the frequency of the CCR $5-432$ mutation was forced up from $10^{-5}$ to present day levels of $10 \%$ by a continuous selection pressure over 320 years (1347 to 1670) of epidemics of a lethal, directly infectious viral haemorrhagic fever. These conclusions are consistent with the fact that the plagues, like the CCR5- $\triangle 32$ mutation, were confined to Europe.

The CCR5-432 containing ancestral haplotype was estimated by the use of coalescence theory to have originated around 700 years ago (range 275 to 1875), coinciding with the date of the Black Death. ${ }^{10}$ However, by this time the gene frequency was at least $5 \times 10^{-5,12}$ and the origins of the mutation must have been much earlier. Libert et $a l^{11}$ conclude that most if not all $\Delta c c r 5$ alleles originate from a single mutation event that took place a few thousand years ago. The rates of crossing over between microsatellite IRI3.1 and $\Delta c c r 5$ place this occurrence some 3500 years ago (95\% confidence interval, 400 to 13000 ), whereas calculations using the frequency of microsatellite mutations estimate that this event occurred 1400 years ago (375 to 3675 ). ${ }^{11}$

We have suggested ${ }^{17} 23$ that the CCR5-432 appeared over 2500 years ago and its frequency was forced up from the initial single mutation ${ }^{10}$ to the frequency in the mid-14th century by sporadic epidemics of haemorrhagic plague which occurred widely over the eastern Mediterranean area during a very long time span. Examples of these outbreaks before the arrival of the Black Death in 1347 include the following:

- Haemorrhagic fevers in the Nile valley in Pharaonic Egypt, 1500 to 1350 BC. The evidence is from medical papyrus sources. ${ }^{24}$

- Haemorrhagic fevers in Mesopotamia, 700 to 450 BC and about 250 BC. The evidence is from the diagnostic handbook prepared during the reign of Marduck-apliddina. ${ }^{25}$

- Plague of Athens, 430 to 427 BC. Thucydides left a detailed description of the symptoms of the disease which correspond closely with accounts of the Black Death. ${ }^{26}$

- Plague of Justinian, originated in Ethiopia, moved down the Nile Valley and onwards to Syria in AD 541 and thence to Asia Minor, Africa, and Europe, arriving in Constantinople in AD 542. Procopius described the symptoms and there are striking similarities, both with the Plague of Athens and the Black Death. The Plague of Justinian continued until AD 700, with epidemics flaring up repeatedly. ${ }^{17}$

- The plagues of the early Islamic empire (AD 627 to 744). ${ }^{26}$

An unpublished report presented at an international conference on ancient DNA at the University of Queensland claims to have detected the CCR5- $\triangle 32$ mutant allele in four of 17 Bronze Age skeletons dating to about 900 BC from a burial site in central Germany. Such findings fit readily within the time course above and suggest that haemorrhagic plague, in addition to the major historic outbreaks, may have been grumbling along in eastern Europe from 1000 BC.

The steady improvement in public health measures contributed to the elimination of haemorrhagic plague by $1670,{ }^{17}$ but the major factor was the sharp rise in the frequency of the $\Delta 32$ mutation in the towns and cities of Europe in the 17th century (fig 3) where the epidemics were largely confined, in contrast with the villages and countryside which were rarely struck. If the overall average frequency of the CCR5- 432 mutation was $10 \%$, the proportion in the larger towns, where the selection pressure was heavy, must have been very much greater. With so many resistant individuals in these conurbations, the population of susceptible individuals did not exceed the threshold density ${ }^{16}$ and, gradually, epidemics failed to explode. The effect was found first in France, the plague reservoir, which had passed its peak by $1646 .{ }^{17}$ Thereafter, England became the plague epicentre, culminating in the Great Plague of London in 1665.

The selective advantage of the $\Delta 32$ mutation was lost once the plague had disappeared after 1670, and its frequency would then be expected to fall slowly by genetic drift over the next 300 years. Two independent factors may have served to maintain the frequency of the resistance allele during this time.

First, preliminary studies have suggested that there are links between protection against smallpox and HIV; older people who had been vaccinated against smallpox were less likely to contract HIV. Experiments with human blood cells have shown that vaccination confers, on average, a fourfold reduction in the infectivity of HIV (unpublished report from George Mason University, Virginia, USA, 2003). Myxoma poxvirus uses the CCR 5 receptor to gain entry to its target white blood cells in rabbits. ${ }^{27}$ Before 1628, when a lethal strain of smallpox appeared in England, the disease would not have exerted any selection pressure on the CCR $5-432$ allele, but we suggest that the resistance mutation may have provided at least partial protection from smallpox in the 17th and 18th centuries, so maintaining the selection pressure on the mutation. Thus non-European races, which were never exposed to plague, might historically be expected to be particularly susceptible to smallpox: American indigenous populations were especially badly hit when smallpox was introduced by conquering Europeans. ${ }^{16}$ When smallpox arrived in the Shetland island of Foula in 1720 less than 10 of 200 inhabitants survived the epidemic. ${ }^{28}$

Second, there is good evidence that haemorrhagic plague did not disappear completely in 1670 but continued in Scandinavia, Poland, Russia, and the European-Asian borders. The plague of Copenhagen in 1711, in which 38\% of the population died, was the last outbreak in Denmark, but the Health Authorities there maintained strict control of its borders because Poland continued to be ravaged at regular intervals until $1800 .{ }^{29}{ }^{30}$ This maintenance of haemorrhagic plague in northeastern Europe provided continuing selection pressure of the CCR5-432 mutation and explains why it occurs at the highest frequency in Scandinavia and Russia.

\section{Authors' affiliations}

S R Duncan, Department of Engineering Science, University of Oxford, Parks Road, Oxford, UK

S Scott, C J Duncan, School of Biological Sciences, University of Liverpool, Crown Street, Liverpool, UK

Competing interests: none declared

\section{REFERENCES}

1 Alkhatib G, Combadiere C, Broder CC, Feng Y, Kennedy PE, Murphy PM, Berger EA. CCCKR5: a RANTES, MIP- $1 \alpha$, MIP- $1 \beta$ receptor as a fusion cofactor for macrophage-trophic HIV-1. Science 1996;272:1955-8.

2 Choe H, Farzan M, Sun Y, Sullivan N, Rollins B, Ponath PD, Wu L, Mackay CR, LaRosa G, Newman W, Gerard N, Gerard C, Sodroski J. The $\beta$-chemokine receptors CCR3 and CCR5 facilitate infection by primary HIV-1 isolates. Cell 1996;85:1135-48.

3 Deng $H$, Liu R, Ellmeier W, Choe S, Unutmaz D, Burkhart $M$, Di Marzio P, Marmon S, Sutton RE, Hill CM, Davis CB, Peiper SC, Schall TJ, Littman DR, Landau NR. Identification of a major co-receptor for primary isolates of HIV-1. Nature 1996;381:661-6.

4 Doranz BJ, Rucker J, Yi Y, Smyth RJ, Samson M, Peiper S, Parmentier M, Collman RG, Doms RW. A dual-tropic primary HIV-1 isolate that uses fusion and the $\beta$-chemokine receptor CKR-5, CKR-3 and CKR-2b as fusion cofactors. Cell 1996:85:1149-58.

5 Dean M, Carrington M, Winkler C, Huttley GA, Smith MW, Allikmets R, Goedert JJ, Buchbinder SP, Vittinghoff E, Gomperts E, Donfield S, Vlahov D, Kaslow R, Saah A, Rinaldo C, Detels R, Hemophilia Growth and Development Study, Multicenter AIDS Cohort Study, Multicenter Hemophilia Cohort Study, San Francisco City Cohort, ALIVE Study and O'Brien SJ. Genetic restriction of HIV-1 and progression to AIDS by a deletion allele of the CKR5 structural gene. Science 1996;273:1856-62. 
6 Huang Y, Paxton WA, Wolinsky SM, Neumann AU, Zhang L, He T, Kang S, Ceradini D, Jin Z, Yazdanbakhsh K, Kunstman K, Erickson D, Dragon E, Landau NR, Phair J, Ho DD, Koup RA. The role of a mutant CCR5 allele in HIV1 transmission and disease progression. Nat Med 1996;2:1240-3.

7 Michael NL, Chang G, Lovie LG, Mascola JR, Dondero D, Birx DL, Sheppard HW. The role of viral phenotype and CCR-5 gene defects in HIV-1 transmission and disease progression. Nat Med 1997;3:338-40.

8 Samson M, Libert F, Doranz BJ, Rucker J, Liesnard C, Farber C-M, Saragosti S Lapoumeroulie C, Cognaux J, Forceille C, Muyldermans G, Verhofstede C, Burtonboy G, Georges M, Imai T, Rana S, Yi Y, Smyth RJ, Collman RG, Doms RW, Vassart G, Parmentier M. Resistance to HIV-1 infection in Caucasian individuals bearing mutant alleles of the CCR-5 chemokine receptor gene. Nature 1996;382:722-5.

9 Marmor M, Sheppard HW, Donnell D, Bozeman S, Celum C, Buchbinder S, Koblin B, Seage GR. Homozygous and heterozygous CCR5- $\triangle 32$ genotypes are associated with resistance to HIV infection. JAIDS 2001;27:472-81.

10 Stephens JC, Reich DE, Goldstein DB, Shin HD, Smith MW, Carrington M, Winkler C, Huttley GA, Allikmets R, Schriml L, Gerrard B, Malasky M, Ramos MD, Morlot S, Tzetis M, Oddoux C, De Giovine FS, Nasioulas G, Chandler D. Aseev M, Hanson M, Kalaydjieva L, Glavac D, Gasparini P, Kanavakis E, Claustres M, Kambouris M, Ostrer H, Duff G, Baranov V, Sibul H, Mepspalu A, Goldman D, Martin N, Duffy D, Schmidtke J, Estivill X O'Brien SJ, Dean M. Dating the origin of the CCR5- $\triangle 32$ AIDS-resistance allele by the coalescence of haplotypes. Am J Hum Genet 1998;62:1507-15.

11 Libert F, Cochaux P, Beckman G, Samson M, Aksenova M, Cao A, Czeizel A Claustres $M$, de la Rua C, Ferrari M, Ferrec C, Glover G, Grinde B, Guran S, Kucinskas V, Lavinha J, Mercier B, Ogur G, Peltonen L, Rosatelli C, Schwartz M, Spitsyn V, Timar L, Beckman L, Parmentier M, Vassart G. The $\Delta \mathrm{ccr} 5$ mutation conferring protection against HIV-1 in Caucasian populations has a single and recent origin in Northeastern Europe. Hum Mol Genet 1998;7:399-406

12 Galvani AP, Slatkin M. Evaluating plague and smallpox as historical selective pressures for the CCR5- $\triangle 32$ HIV-resistance allele. Proc Natl Acad Sci USA 2003;100:183-8.

13 Mecsas J, Franklin G, Kuziel WA, Brubaker RR, Falkow S, Mosier DE. CCR5 mutation and plague protection. Nature 2004;427:606
14 Razzell P. The conquest of smallpox: the impact of inoculation on smallpox mortality in eighteenth-century Britain. Chichester: Caliban, 1977.

15 Creighton C. History of epidemics in Britain. Cambridge: Cambridge University Press, 1894.

16 Scott S, Duncan CJ. Human demography and disease. Cambridge: Cambridge University Press, 1998.

17 Scott S, Duncan CJ. Biology of plagues. Cambridge: Cambridge University Press, 2001.

18 Duncan CJ, Scott S. What caused the Black Death? Postgrad Med J (in press).

19 Livi-Bacci M. A concise history of world population. Cambridge: Cambridge University Press, Cambridge, 1997.

20 Biraben JN. Les hommes et la peste en France et dans les pays Européens et Méditerranéens. Tome I. La peste dans l'histoire. Paris: Mouton and Co and École des Hautes Études en Sciences Sociales, 1975.

21 Duncan SR, Scott S, Duncan CJ. Time series analysis of oscillations in a model population: the effects of plague, pestilence and famine. J Theoret Biol 1992; 158:293-311.

22 Coale AJ, Demeny P. Regional model life tables and stable populations. New York, Academic Press, 1983

23 Scott S, Duncan CJ. Return of the Black Death. Chichester: John Wiley, 2004

24 Panagiotakopulu EJ. Pharaonic Egypt and the origins of plague. J Biogeog 2004;31:269-75.

25 Coleman M, Scurlock J. Viral haemorrhagic fevers in ancient Mesopotamia. Trop Med Int Health 1997; 2:603-6.

26 Dols MW. The Black Death in the Middle East. Princeton: Princeton University Press, 1977.

27 Lalani AS, Masters J, Zeng W, Barrett J, Pannu R, Everett H, Arendt CW McFadden G. Use of chemokine receptors by poxviruses. Science 1999:286:1968-71.

28 Smith JR. The speckled monster. Hunstanton: Witley Press, 1987.

29 Christensen P. Copenhagen 1711: Danish authorities facing the plague. In: Sheard S, Power H, eds. Body and city. Histories of urban public health. Aldershot: Ashgate Publishing, 2000

30 Christensen P. "In these perilous times": plague and plague policies in early modern Denmark. Med Hist 2003;47:413-50. 